vantage to have the nerve trying dulies of an attendant upon the dimgerous insine daty eompared with the lesis onegons duties of those who guard same men serving short sentences for drunkenness or vagrancy. These and other intereurrent influences make against the morale of nutses and attendants who atre for the criminal insane.

If we were laceing the problem of providing for the eonviet and oriminal insane, with no momey invested in a plant, we would like to select. a hundred aceses of rough, high land adjacent. to some railroad and abundantly supplied with water. 'Jo build ecomominally the prison popubation of the state ought to be omployed, and this means that the work must be clone under the auspices of the prison rommissioners, of of the State Board of eharity which has jurisdiction over the prison department of the sitate Farm. But, we ean build " eastles in sipain" and hospitals for the eriminal insane, in imagination, without an appropriation of the eomsent of any one.

We appreciate and sympathize with the sentiment, which has torn (lown the walls of the airing courts which formerly offended the eye in ronnection with many hospitals and asylums, but in building for six hundred or more eriminal insane I would advise inclosing fifty areses or more with a stone wall that eould be ilepended on to keep the publie out and the patients in exeept hy suitably guarded exits and entrances. These walls would be so late distant from the buildings as not, to sugerest the conventional airing court of the old-time asylum at all. If the buildings stood on the highest elevation the top of the walls might be below the level of the foundations of the buildings and still be effective. If the whole surrounding wall was well lighted at night and adequately patrolled there would be little incentive for patients - truly insane or malingerers-. seheming with friends outside for saws, or making keys to lead them to liberty. In other words, oul outer defenses should be of the most eomplete prison eonstruction (o safeguard the public, while within the gates our eonstruction should be simple and of the most, approved hospital designs for the progress of science and the cure of discase.

()ne hospital building proper, thoroughly equipped after the mamner of a eomplete general hospital, should be within the gates, yet some distance from the asylum buildings. It might have four open wards of fifteen beds each, with lifteen single rooms anditional for selected aises. It should have its own kitehen and dining-room, as well as sun room and reading room, and have a trained woman nurse in eharere, assisted by the necessary number of men nurses. $A$ s an arljunct to this acute hospital building there should be an extensive hydriatic plant with a competent physi(all instructor in charge who should teach the whole attendant body the arl of the masseur and the principles and practice of hydrotherapy and physical training. Not only the aceute eases should here be treated, hut a considerable perientage of chronic cases (ap)able of physionl improvement should be sent, here daily as " ontpatients" for their own good and for the good of the student, body reeceing instruction in this

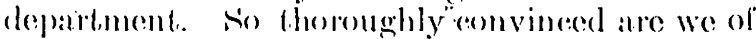
the value of the sol-alled physiological theralpy that we would eount money well spent, in developing this line of treatment 10 its highest, plane. Another specially anstructed huilding, with its own kitehen, sim rooms and broald porehes. where pationts eomlal be moveel on wheeled ehatis and beds to sit or slecep in the open air, and whereled into a warmed rown for ehanes of elothing or bedeling. would he needed for the tubereatlous. Shateks and tents might well help out in summer for selected atses, but there is usually a reason why a man with a sentence should be provided with substantial areommodations.

for other huldlings within the gates wo would not ask better than duplieates of the more recently anstructed asylum buildings at Sitate? farm, exeepte a detached bulding for the eonvaleseing and the quiet men of good eomduet amol homorable previous record, who are only techuially eriminals. 'This should be apart and have its own dining-room, walks. flower beds in stmmmer and sheltering grove.

Outside the wates, beside ale(ommodations for the superintendent and other medical oflieers. we would have modest rot tages built hy the stale and rented to married muses and attendants at a price just covering interest on investment and cost of repariss. A remfortable murses' home, with reading room and rooms for recreation for those who have not eome to their birthright, would be an essential part of the plan. The selheme includes such wages for eompetent nurses and attendants as will enable a man to mary and live in modest eomfort and be redained for vears, if competent, as a professiomal nurse and atifendant. (in the insane.

Sueh are some of the essential features of the hospital for insane criminals we have huilt, without an appropriation from the stuff of which dreams are made.

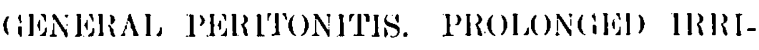
(IATION OI' THIS ABIOOMINAT, GAVIT'.

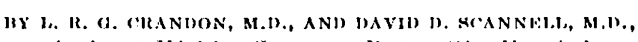

Assistant Visiting Surgroms, Bostom ('it!l Ilospital.

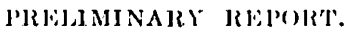

1. THu roble of drainage of the whole abdominal eavity is limited, besause of:

(a) The relative infrequency of miversil infection of the abdominal eavity.

(b) The chance, by all present methods of drainage, of earrying infection to a part as yet uncontaminated.

(c) The insullieiencey of present, methods of drainate.

2. If dranage has to be established it should be such that:

(a) The maximum drainage should take place.

(b) The least disturbance to intestines and other viscera should be suffered.

(c) The drainage should he eomtinuous, or at, least be continual. 
(d) The dranage apparatus should be remos- female, or between the bladder and rectum in alle with the least disturbance.

3. The apparatus devised and used.

1. ('onclusions on the present atalus of dominal drainage.

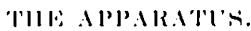

The fourth tube (the appendix tube) extends along the abdeminal wall to end over the eecum.

Winch tube, at its exit, is protected by two erossed pieres of nickeled wire to prevent the intest ine being sucked into the tube when siphonatge

Having the intention to wash and drain thor- is established. From the side of the reservoir oughly the infected aldedominal eavity, with the rums a rubber tube three or more feet long. The least injury to, and disturbance of. the abdominal foy of the reservoir is a serew-top eap. Into the contents. we have devised and used this appatra- opening of each tube, at the bot tom of the reserlis:

voir, may be serewed a brass plug to chose one or

It comsists of a small reservoir (eapacity $10 \%$ ) several of the fubes if needs be. The instrument of niekeled brass supported on an ahuminum a can be perfeedly sterilized, there being no eompliplate, in its turn resting on the anterior ilias fated parts.

spines. From the bot tom of this reservoir emerge Jse of the apparatus. -.. The primaly eause of four nickeled tubes, 1 em. in diameter, easily the peritonitis is found and repaired or removed removable and self-retaining.

if possible. 'Through a median suprapubie in-

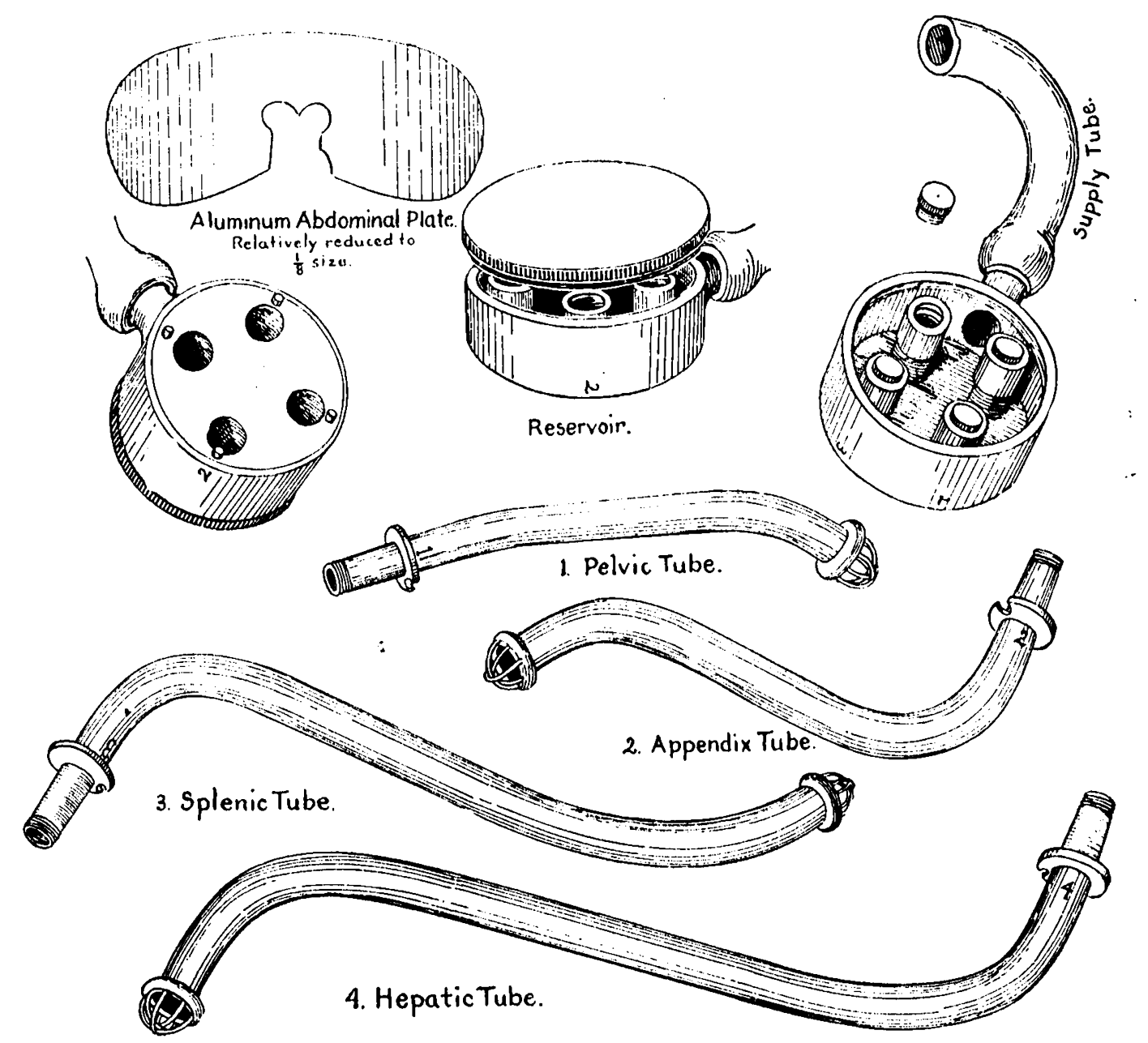

The tube first to be inserted (the hepatic tube) deision, thee inches long, the hepatic and splenie runs along under the abdominal wall, etures tubes are inserted and pushed gently along, slightly, and ends hanging over the hepatic fossal lifting the abdominal wall, toward their respecneap the hepatic flexure of the large gut.

five fossat. 'The pelvic tube is guided by the

The second tube (the splenic tube) runs along finger in its proper direetion; and the appendix heneath the abdominal wall to end over the tube in a similar manner. Fath tube as it is put splenic region.

into place is snapped into its proper hole in the

The third tube (the pelvie tube) runs from the bottom of the reservoir.

reservir down into the pouch of Douglas in the The bottle of salt solution is now connected 
with the distal end of the rubber supply-tube of the reservoir, the fluid passes down through the reservoir out through each of the four tubes, and is allowed to run in uitil the aldomen is distended and fluid begins to leak through the wound about the reservoir. The supply-tube is detached from the water bottle, pinched at the end at the same time to keep it, full of fluid, and is then lowered to below the level of the patient. This eolumn of water in the supply-tube at onee establishes siphon-drainage and the abdomen is drained at least till the end of me inner tube is above the level of the remaining fluid.

This alternate flooding and draining of the abdominal eavity ean be done as often as one pleases without disturbing the patient, the amount of pressure-influx being regulated by the height of the supply bottle.

Dressings are now applied; the whole appanatus is supported by the aluminum plate which rests on the pelvis, and the patient is moved to bed. Here the abdominal eavity may be flushed out every fifteen minutes, or every hour, or at any interval which may secm best and quite without discomfort to the patient.

This apparatus is mechanically successful, and on the andaver sureceds in reaching and flushing the most remote parts of the abdominal eavity, and draining them. 'The proper eurves and lengths of these four tubes were determined by measurements and experiments on many cadavers placed at our disposition by the kindness of Professor Dwight of the Harvard Medical Sohool.

We have had opportunity to use it in only one atase clinieally. This was in a case of general purulent peritonitis with marked distention following a neglected appendicitis. 'The appendix stump was hastily tied off through the median incision, the apparatus was inserted in a minute and one half, the eavity flushed until the fluid ran clear, and the patient put to bed with the anparatus still in position. The pulse rose during the operation, which in all took twelve minutes, from 124 to 130; about an hour after the operation it, was 110. Siphonage was carricd out every hour for three times, omitted six hours, and then repeated every two hours for three times. The first fluid returned turbid from several washings, but on the next day came slear as if the distended eoils of the paralyzed gut had oceluded the tubes. The case was thoroughly septic, practically without hope from any treatment, and died.

It has been clearly shown by Yates, ${ }^{1}$ in a careful and exhaustive research, that the total value of general peritoneal drainage, if there be any, is in the first twelve to forty-eight hours, be it with grauze, rubber-dam or other form of wick to promote capillary drainage, or with tubes even though favored by gravitation as through the vagina. General drainage is efficient only for a short time. Whatever the form of dranage used, the foreign body is quickly encapsulated by adhesions of the omentum or intestines. Moreover,

1 Yates, J. I.: An lixperimontal stumly of the Iocal Diffects of l'eritoneal J)rainnge. Surgery, (iynecoloky and ()bstetries, Chicago, 1905, i, 1. 477. the material drained by whatever means entployed is not pus or blood, but rather as Coe ${ }^{2}$ remarls: "Of eourse, there is always a considerable discharge of fluid, but this is not the septiemat erial we wish to remove." The free discharge of serous fluid which eomes during the first hours of drainage (1) eomes not from the general peritoncial cavity, but only from the region drained, and (2) the amount, of this drainage seems to be in proportion to the number of wicks. In short, some of the drainage, without question, is excited by the foreign body. In other words, the eridence of the literature and experimental work. such as that done by Yates, seems to show that drainage of the general eavity, exeluding therehy localized absecsses, is, on aceount of the constantly appearing plastic: reaction of the peritoneum, meohanically and clinieally impossible. The present, method of establishing drainage from localized peritonitis, as in the eigarette drain (ganze wrapped in rubber-tissue), is a sign of recognition by surgeons that the main function of the gatu\%e "drain" is to excite adhesion, and thus isolate a septic process from the general eatrity. Yates sums up the objections to attempts at drainage thus: "The most; insurmountable objections to general drainage is, however, noteworthy. Fiom the time that Chassargnac's tubes were found plugrged with fibrin, in the uneonscious admission of lineberle that all serous surfaces applied themselves tightly to his tubes, when he made the apertures small enough to prevent herniae, and by proof that Hegar's theory of capillary drainage by gauze was erroneous, and from clinical experience down to the present time, there has accumulated an array of facts that justify this main objection to general peritoneal drainage; it does not drain the general peritoneum."

Yates's conclusions seem to us mainly sound and we feel it importint to quote them in full:

" Drainage of the general peritoneal cavity is physically and physiologically impossible.

"The relative encapsulation of the drain is immediate.

"The absolute encapsulation occurs early (less than six days in dogs), and can be retarded, but not prevented.

"The serous external discharge is an exudate due to the irritation of eontiguous peritonemm by the drain.

"There is a similar inward eurrent from the potential into the general cavity.

"This external exudate diminishes remarkably with the formation of encapsulating adhesions.

"These adhesions, under approximately normal conclitions, form about any forejen body.

"Their extent and density depend on the degree and the cluration of the irritation of this body.

"Primarily fibrinous, these adhesions become organized in a few days (three days in dogs).

"If the irritation persists, they heome progressively more mature fibrous tissue.

"After irritation reases, their disapponarance

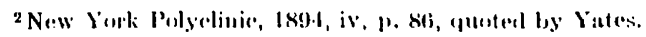


depends principally ujon a mechanical factor, -.the ability of the involved surfices to pull themselves or to be pulled loose.

"Jatains should be the least irritating. and should be gradually but finally removed as soon as possible.

"J Irigation through drains is fulite fo prevent, allosions, and dangerous.

" $\Lambda$ fter" a drain is inserted, all intra-abdominal movements should be redued to a minimum.

"As soon ats the drain is removed, intratil)dominal activity should be stimulated, to aid in the disappearane of the remaining athesions.

"Peritonitis, if not, too severe, possibly aids in the rapidity of the encapsulation of the drain.

" $\Lambda$ drain in the presence of infection is deleferious to peritoneal resistance, and should only be introdued to exchude more malign influenees.

"Postural methods, unless destined to facilitalle encapsulation, are loth futile and hatrmful, as far as drainage is encerned.

"Peritomeal drainawe must he boeal, and unless there is something to be ganed by rendering :m area extraperitoneal, or maling from such an area a safe path of least resistance leading out side the body, there is, aside from hemostasis, no justifieation for its use."

Being envinced of the general soundness of these conchusions, particularly so far as they bear on the malter of general drainage of the whole peritomeal cavity, we have attempted by our apparatus to prepare a moans (1) to irrigato thoroughly the infected (a) vity, and (2) to supply thrount the lymphaties of the peritoneum to the foxic blood a large supply of salt solution, to aid the body to fight and to eliminate foxins.

\section{Glinical gDepartment.}

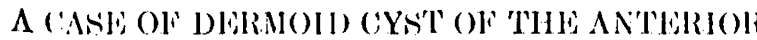 MLIDIASTINUM.}

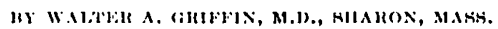

The following case is interesting becaluse of the rarity of the eondition, Morris, of Ann Arbor, loing able to find aceounts of but 57 eases in the literature.'

The patient, a boy of fifteen years, was first soen by me Aug. 14, 1905, on recommendation of Dr. (Clariee J. larsons, of Sipringfield. 'The following hist ory was ohtained. Family history: lathor's father died of aredident. Father's mother died of ameer of the stomach after an illness which lasted more than a lear, and which was charaterized by sharp pain in Ho epigast rimm. What other symptoms were present rould not, be aserertained. Mother's father and mother alive and well. Father and mother of patient also well. lersomal history: The patient was never very rugered. When these vears old he had " eatarth of the bowels," with at taicks of (onstipation allernating with the passiges of murh mucus and blood. This condition lasted, off and on, for two or three years. This was the only sickness that hat erer amounted to anything. Five years ano there was a little hateking

'Med. News, Aug. 26, 1005. rough lasting for a short time, and in last two or three years there have been oceasional athaseks of conghing, but never aty sputa. 'lhere has never been any fever so far ats known and never any pain exeept about, eight months ago, when complaint, was made of pain in the chest, but neither patient. nor mother eould remember which side: was affected. It could not have: been very severe since the boy's mother had always taken full care of him and had evidently kept alose watch of all symptoms. At about the same time that, the pain was noticed the patient began to be somewhat, short of breath and to have huskiness of the voiece. Some two months ago the patient's mother began to notice that the right side of the ehest was fuller in appearanes than the left, but she had never spoken of this to any onc.

The patient looked pale and wather thin. The: general musculature was decidedly below parr, and when wallking there was well-marked stooping. Physieal examination was negative except, for the ehest. 'There was dulluess on the right, side begimning at the second rib, the note rapidly becoming flat on going downward and mergine with the flatness of the liver. 'The dullness extended upward under the sternum to the level of the first interspace and merged to the left with the heart dulluess. The respiratory somels were much diminished over this area and tactile fremilas eould not be felt. In back, on the contrary, there wats gool pereussion note throughout on the right. side exeept for slight, dullness below the angle of the seapula. IIere respiration was broncho-vesieular and tactile fremitus was a little increased. $\Lambda$ few finc râles eould be heard here (the only ones anywhere to be mate out.). $\Lambda$ t the top of the ehest on both sides the respiratory murmur was exigrgerated. The left border of the heirt could be made out two fingerbreadths outside the nipple line, and the lower border of the liver was just below the costal margin. In the right axilla there was a gland the size of an almond, and in the right side of the neek there were one or two the size of a peit. Urine and blood examinations were negative. At this time the case seemed to be one of encipsulated pleuritic effusion, or else a maligmant, growth.

$\Lambda$ farge-sized aspirating needle was introduced in the fifth interspace in the anterior axillary line and with considerable difficulty about two ounces of thick, plairy, dark-ereen fluid was obtained. This fluid showed nothing chatracteristice under the microseope and was sterile on culture after twenty-four hours. On the next day the pleural eavity was opened by removial of a portion of the sixth ril) in the mid-ixilli. By this meatus a small amount, of the same viscid fluid was obtained. (On looking into the wound a tense tumor mass was seen on a level with the incision. Into this a trocar was introdueed and more fluid was obtained, together with a number of bright yellowish masses varying in size from a pin head to a pea. By enlarging the opening into the eyst the wall was explored with the finger. It was found to be about, at quarter inch in thickness and firm of strueture. On that part of the wall which was nearest the diaphragn three or four sessile projections could be felt 'This was the only wall of the eyst, to be made ont. $\Lambda$ drainage tube was introduced and the operation was terminated.

Il did not oceur to me or my assistants at this time that we were dealing with a dermoid eyst. Rather it appeared that the case was one of streptothricosis, this iden being suggested by the yellow granules in the discharge. Some of these were crushed under a coverglass, but no 